\title{
A PRELIMINARY ASSESSMENT OF MINERAL DUST OUTBREAKS IN ITALIAN COASTAL CITIES
}

\author{
MAURO MORICHETTI ${ }^{1}$, GIORGIO PASSERINI $^{1}$, SIMONE VIRGILI $^{1}$, ENRICO MANCINELLI $^{1} \&$ \\ UMBERTO RIZZA ${ }^{2}$ \\ ${ }^{1}$ Department of Industrial Engineering and Mathematical Science, Marche Polytechnic University, Ancona, Italy \\ ${ }^{2}$ Institute of Atmospheric Sciences and Climate, National Research Council of Italy, Lecce, Italy
}

\begin{abstract}
The Mediterranean region, being the area well known for its predominantly mild climate, has been subject to human intervention for millennia. The fast population growth and its intense rural and transportation activities are the main responsible factors that contribute to increasing anthropogenic airborne pollutant emissions. In addition to anthropogenic emissions, the area is influenced also by natural emissions such as episodes of wind-blown mineral dust from the Sahara Desert. In order to assess and speciate the growing emissions over the Mediterranean region, we used WRF-Chem chemical transport model. One-year modellings based on two distinct simulations, have been carried out: the first considering only mineral dust ('DUSTONLY' simulation) and the second one considering other types of emissions, such as biogenic and anthropogenic ('MOZMOSAIC' simulation). Both simulations use the Goddard Chemistry Aerosol Radiation and Transport dust emission scheme. The National Centers for Environmental Prediction (NCEP)/National Center for Atmospheric Research (NCAR) reanalysis data were used to assess the accuracy of simulated meteorological fields such as temperature, relative humidity and wind speed and direction, showing a great capability of WRF-Chem to model the experimental fields and their spatial trends. The comparison between the modelled dust column mass density and the same field calculated through the corresponding Modern-Era Retrospective Analysis for Research and Applications, version 2 (MERRA2) reanalysis showed an evident dust load overestimate over North Africa. Such overestimate is confirmed by the comparison of both simulations with the AERONET aerosol optical depth (AOD) $(550 \mathrm{~nm})$ products: Rome and Naples stations have nearly the same trend and AOD peaks are captured well, but the dust concentrations are overestimated from both simulations.
\end{abstract}

Keywords: dust outbreak, GOCART dust emission, MOZART chemistry, MOSAIC aerosol, WRF-Chem.

\section{INTRODUCTION}

Various studies showed the influence of anthropogenic and natural aerosols on the atmospheric and terrestrial systems with an increasing interest in climate processes. Atmospheric aerosols, along with clouds, have a considerable effect over the radiative energy balance of the Earth's ecosystem. Considering the aerosol total mass, the mineral dust is the main atmospheric natural aerosol; it includes up to $75 \%$ of the global aerosol mass and, therefore, plays a very important role in the earth radiative system [1]. The aerosol particles interact with the atmosphere through direct and indirect effects. The direct effects are due to the particle scattering and absorption capacity that have consequences in the net heating rate, while the indirect effects are due to the interaction of particles with clouds. For instance, they can affect the radiative budget via altered cloud properties, such as cloud drop size, cloud lifetime and cloud thickness [2-4].

The Sahara desert is the main source of mineral dust on the planet: about half of the total emissions is generated in the Sahara desert [5]. The convection, produced by strong surface heating, can lift dust particles for several kilometres into the free troposphere and transport them over large distances. While a significant fraction is transported westward across the Atlantic Ocean, large quantities of mineral dust are also transported across the Mediterranean Sea to Europe in episodic events (outbreaks) [6,7]. During the outbreaks, mineral dust 
particles become the major component of PM10 in urban and rural sites of the Mediterranean basin, contributing to a significant percentage of pollution episodes. At European level, the areas most affected by the presence of such aerosols are Italy, Greece and Spain [8].

The studies of the mineral dust transport are getting increasing attention from the scientific community allowing better investigation about its impact on the terrestrial radiation budget, on the microphysics of clouds as well as on air quality and human health. The mineral dust emission parameterization and the relative transport are still difficult to determine due to the uncertainties related to the extensive nature of emissions, the nature of the soil, the aerosol chemistry complexity and the meteorological conditions. However, intensive measurement campaigns have been conducted to increase our understanding of the effects of dust pollution [9]. In addition to the measurement campaigns, satellite observations provide crucial information on the global distribution of dust (e.g. MODIS - moderate resolution imaging spectroradiometer). Finally, the AERONET network (aerosol robotic network) provides considerable information on the optical and physical properties of aerosols [10]. Furthermore, thanks to the simulations of dust intrusions by global and regional chemical/climate models (e.g. GEOS-CHEM [11], CAM-CHEM [12], Modern-Era Retrospective Analysis for Research and Applications, version 2 (MERRA-2) [13] and WRF-Chem [14,15]), a more accurate understanding of the aerosol parametrization and transport can be now obtained. The numerical models applied in previous studies, to simulate the Saharan episodes over the Mediterranean Basin, present a wide diversity in simulating the transport of dust, as also evident in a recent study concerning a comparison of a set of nine simulations of regional models of mineral dust on Europe [16]. This can be attributed to different parameterizations of emission models and to different deposition schemes, as well as to various model configurations and soil surface properties $[17,18]$.

Most of the mineral dust sources are in arid and semi-arid regions that extend from the west coast of North Africa, the Middle East and into the Central Asia. The global mineral dust emission rates are estimated in a range between 1,000 and 3,000 Tg/year [19]. The dust emissions from the Sahara desert range between 500 and 1,400 Tg/year, contributing to about $50 \%$ to $70 \%$ of total emissions [20,21]. The Bodélé depression is one of the driest places on earth and one of the most important point for dust emissions in the Sahara desert, due to the erodibility of the surface material and the wind erosion potential [22]. It is estimated that such small area produces about $50 \%$ of Saharan mineral dust deposited in the Amazon rainforest $[23,24]$.

Satellite images and measurements confirm that the mineral dust emitted from the Saharan desert can be transported to great distances. In spring/summer, the air over North Africa is loaded by a considerable amount of mineral dust; low-pressure systems called 'Sharav cyclones' activate the suspended mineral dust and transport it to north and to east along the Mediterranean coast. Storms of mineral dust begin to appear in the western Mediterranean and move eastward, and most of them travel at least to the eastern Mediterranean coast [25].

\section{MATERIAL AND METHODS}

To perform the assessment of Saharan dust outbreaks to the Mediterranean basin, the chemical transport model WRF-Chem version $3.9[14,15]$ was applied for the whole of the year 2017 (from 1 January 2017 00:00 UTC to 1 January 2018 00:00 UTC) to outline the seasonal changes and the mineral dust outbreaks occurred during this period. The model domain covered most of northern Africa and southern Europe, the areas that could be affected by the Saharan dust outbreaks (e.g. Italy, Spain, Portugal and Greece). The domain has 430×330 grid 
points centred at $30^{\circ} \mathrm{N}$ and $10^{\circ} \mathrm{E}$ with a horizontal grid spacing of $15 \mathrm{~km}$ and 40 vertical levels up to $50 \mathrm{hPa}$.

The initial and boundary meteorological conditions were provided by ERA-Interim, while the latest global atmospheric reanalysis was produced by the European Centre for MediumRange Weather Forecasts. The system includes a four-dimensional variational analysis (4DVar) with a 12-h analysis window. The spatial resolution of the dataset is approximately $80 \mathrm{~km}$ on 60 vertical levels from the surface up to $0.1 \mathrm{hPa}$ [26]. The static geographical fields, such as terrain height, soil properties, vegetation, land use and albedo, were interpolated from 30-arc second ( 900 m) United States Geological Survey maps to the model domain by using the WRF pre-processing system (WPS). Four-dimensional data assimilation (FDDA) technique was also applied to limit the model errors in the simulated meteorological fields [27,29].

Two simulations were run to assess the impact of the Saharan dust outbreaks on the Mediterranean basin: the first one, with the 'dust-only' option, and the second one, with the chemical option using MOZART (model for ozone and related chemical tracers version 4) [30-33] for the trace gas fragment and MOSAIC (model for simulating aerosol interactions and chemistry) [34] for the aerosol phase species. In the first simulation, no other emission has been added (anthropogenic, biomass burning and biogenic emission). The second simulation is more comprehensive as the EDGAR-HTAP (Emission Database for Global Atmospheric Research) emission inventory was used to provide the anthropogenic emissions, while the biomass burning emissions were obtained from the database FINN (Fire Inventory from NCAR) [35]; other biogenic emissions were obtained from MEGAN database and the chemical boundary data for both gas and aerosol were provided through the MOZBC pre-processor.

\section{RESULTS}

\subsection{WRF-Chem modelling of meteorological fields}

The evaluation of meteorological parameters was performed considering NCEP/NCAR [36] reanalysis products to examine spatial patters (i.e. wind speed at $10 \mathrm{~m}$, temperature and relative humidity at $2 \mathrm{~m}$ ). The following maps show the spatial distribution of the monthly average for temperature $\left({ }^{\circ} \mathrm{C}\right)$ and relative humidity $(\%)$ at $2 \mathrm{~m}$ (Fig. 1) and the wind speed $(\mathrm{m} / \mathrm{s})$ and direction at $10 \mathrm{~m}$ (Fig. 2). For each variable, the left column shows the modelled values (WRF-Chem results with $15 \mathrm{~km}$ grid cells), while the right column shows the NCAR/NCEP reanalysis products (46) (horizontal resolution of $2.5^{\circ} \times 2.5^{\circ}$ ). The plots show the four annual seasons: winter (January), spring (April), summer (July) and autumn (October).

The WRF-Chem monthly average temperature compares well with the reanalysis data and its spatial trend. Overall for all seasons, model and reanalysis results are in a good agreement, showing the same temperature development from the central-east European area to the Mediterranean Sea, near the North Africa coast, emphasizing a temperature rise in the southeastern direction. The monthly average of relative humidity shows a suitable correlation, and a very similar spatial tendency, between the model and the reanalysis data. Changes in the relative humidity magnitude, related to the seasonal development, are well noted. The modelled wind speeds and directions show an appropriate agreement with the NCEP/NCAR reanalysis. In general, wind directions are better captured than wind speeds.

The selected meteorological parameters (i.e. temperature, relative humidity and winds) have been analysed since the aeolian erosion in semi-arid regions occurs only when a threshold value of the surface friction velocity is reached depending on the soil moisture and surface 

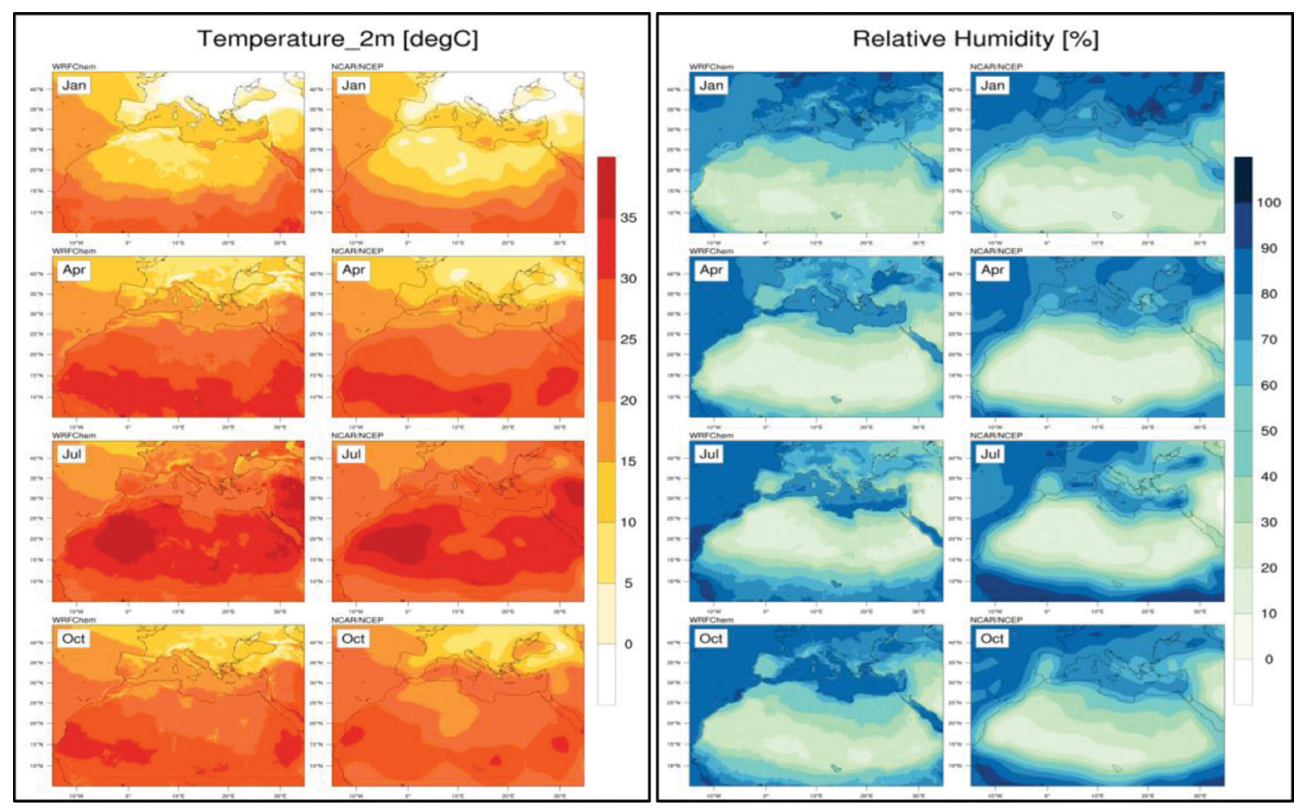

Figure 1: Spatial distribution of monthly average temperature $\left({ }^{\circ} \mathrm{C}\right)(\mathrm{left})$ and monthly relative humidity right at $2 \mathrm{~m}$ : comparison between the NCAR/NCEP reanalysis (right columns) [36] and WRF-Chem results (left columns).

features and then on the land surface scheme used [18,37]. Thus, the production and transport of dust aerosols depend substantially on the accuracy of simulated meteorology and the land surface schemes.

\subsection{WRF-Chem modelling of aerosol phase}

The aerosol spatial distribution modelled by WRF-Chem was compared, in terms of total mass distribution, with MERRA-2 [13] reanalysis and, in terms of optical properties, with MODIS retrievals [38] and AERONET data [39]. The MERRA-2 is the newest atmospheric reanalysis produced by NASA's Global Modeling and Assimilation Office with a spatial resolution of about $50 \mathrm{~km}$. The MERRA-2 includes aerosol assimilation obtained by MODIS and AERONET. The aerosols are integrated by using Goddard Chemistry Aerosol Radiation and Transport (GOCART) model [40].

The MERRA-2 dust column mass density has been compared with the dust column mass density from the 'dust-only' simulation. The 3-month average of the dust column mass density is represented in Fig. 3: April, May and June are the most active for the dust transport [1]. Figure 3 shows that WRF-Chem overpredicts the MERRA-2 reanalysis data by a factor of about 10 in the most part of North Africa (Sahara desert) and by a factor of about 2 in the Mediterranean basin.

Since the WRF-Chem 'dust-only' chemistry option does not explicitly calculate the aerosol optical properties, its output file does not contain the related fields. Since the vertical summation of each extinction coefficient field multiplied by the related layer depth represents 


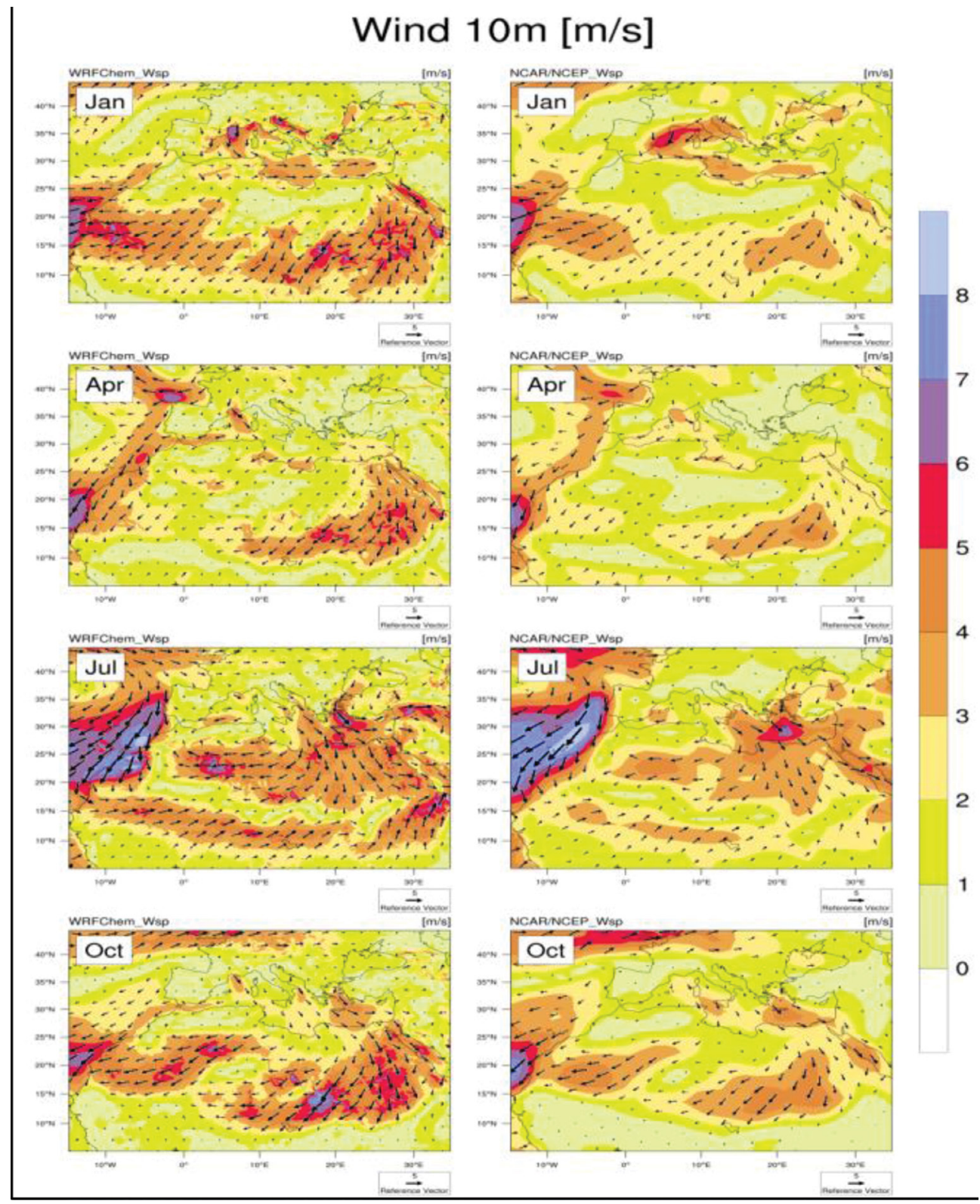

Figure 2: Spatial distribution o of winds at $10 \mathrm{~m}$ (colour contour maps show the wind speed $(\mathrm{m} / \mathrm{s})$, black arrows show wind direction): comparison between the NCAR/NCEP reanalysis (right column) and WRF-Chem results (left column).

the computed aerosol optical depth (AOD) at a particular wavelength, to calculate the AOD, the associated equation proposed by Chang et al. [41], adapted to dust load, was introduced:

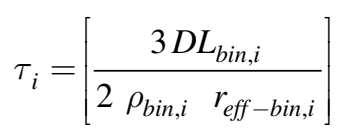




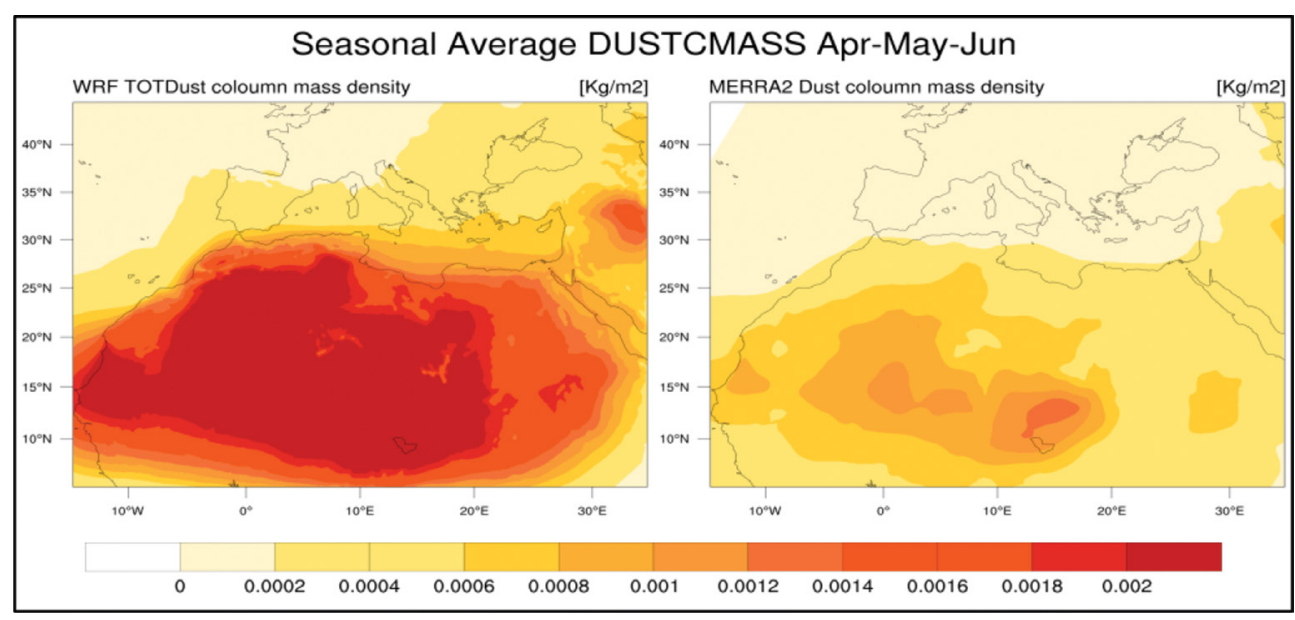

Figure 3: Spatial distribution of the 3-month average of the dust column mass density $\left(\mathrm{kg} / \mathrm{m}^{2}\right)$; 'dust-only' WRF-Chem simulations compared with MERRA-2 dust outputs.

where

- $D L$ is the dust load of the bin $i$ th $\left(\mathrm{kg} / \mathrm{m}^{2}\right)$;

- $\rho$ is the density of the bin $i$ th $\left(\mathrm{kg} / \mathrm{m}^{3}\right)$;

- $r_{\text {eff }}$ is the effective radius of the bin $i$ th $(\mathrm{m})$.

The AOD at $55 \mu \mathrm{m}$ was calculated as follows:

$$
A O D=\sum_{i=1}^{n-1} \text { extcoef } 55 \times \Delta z_{i}
$$

where

- extcoef55, as output from the model, is the extinction coefficients for $55 \mu \mathrm{m}$ wavelength;

- $\Delta \mathrm{z}_{\mathrm{i}}$ is the i-layer depth between $z_{i}+1$ and $z_{i}$.

Figure 4 shows the comparison between monthly average AOD of the 'dust-only' simulation calculated with such equation and the MODIS AOD retrievals. The discrepancies of AOD values over Europe are significant in April and May and less important in June. A remarkable similarity in the AOD spatial distribution occurs over North Africa and other regions dominated by dust, showing the same spatial AOD development with higher values located at the well-known dust emitting points [1]. On the other hand, a notable AOD overprediction is visible in the Saharan region, regardless of the considered month: the WRF-Chem model largely overestimates AOD.

Preliminary results, shown in Fig. 4, indicate that 'dust-only' and 'MOZART-MOSAIC' runs show comparable distributions of mass and AOD optical properties. However, both distributions reveal a large overprediction both in terms of mass when compared with MERRA-2 reanalysis and in terms of optical properties when compared with MODIS retrievals. This means 

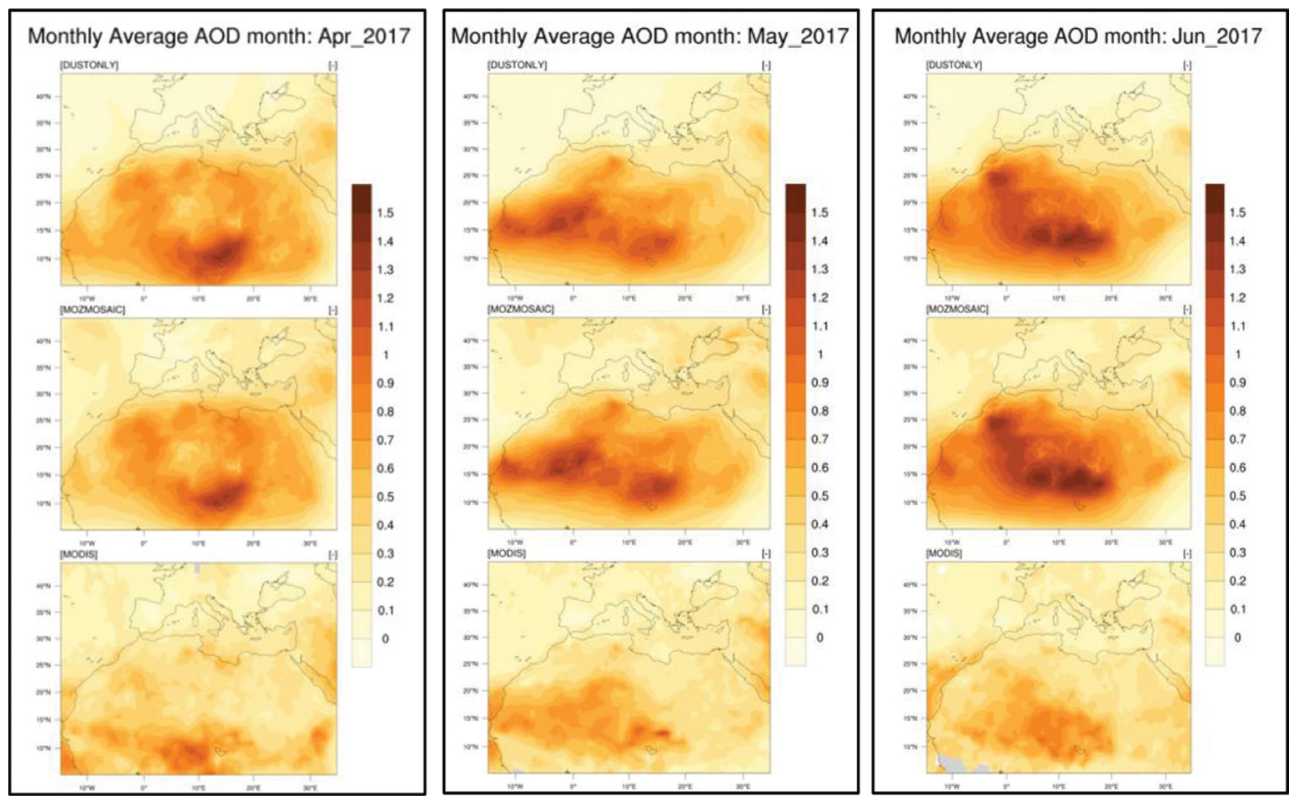

Figure 4: Monthly average AOD spatial distributions: 'dust-only' WRF-Chem simulations (top), AOD at $550 \mathrm{~nm}$ for the simulation considering the 'MOZART-MOSAIC' chemical option (centre) and MODIS AOD product (low) for April, May and June 2017.

that different chemistry/aerosol phases (GOCART/GOCART for dust only and MOZART/ MOSAIC for the second one) produce only small differences when simulating dust advection and, thus, that the amount of dust emitted by the GOCART scheme should be in some way reduced.

The last stage of the present study was the comparison between the daily average of AOD at $550 \mathrm{~nm}$ of the two simulations described above and the AERONET AOD level 2 data (i.e. cloud-screened and quality assured) at selected stations located in central and southern Italy, regions where the dust outbreaks are more intense [7, 42]. Five stations were selected: Rome, Naples, Lecce, Aquila and Potenza. At Rome station (not shown), both simulations overpredicted the AOD value. Naples AERONET station shows the same trend as Rome but shows the largest overprediction in the beginning of the year (not shown). The fourth week of April, in Lecce station (Fig. 5), shows a noteworthy episode in which all the data are very close $\left(\mathrm{AOD}_{\mathrm{D} 17}=1.2 ; \mathrm{AOD}_{\mathrm{M} 17}=0.9 ; \mathrm{AOD}_{\mathrm{AER}}=1\right)$, due to a dust intrusion in Southern Italy that occurred during 26-30 April 2017.

\section{CONCLUSIONS}

The aim of the present study was to model Saharan dust intrusions in southern Europe and to find out their effects on air quality in selected Italian cities. This was achieved considering two WRF-Chem simulations over 1 year (1 January 2017 00:00 UTC to 1 January 2018 00:00 UTC). Model was configured at first to have a simulation, where only the dust emissions were considered and computed ('dust_only') and then to achieve a more comprehensive 


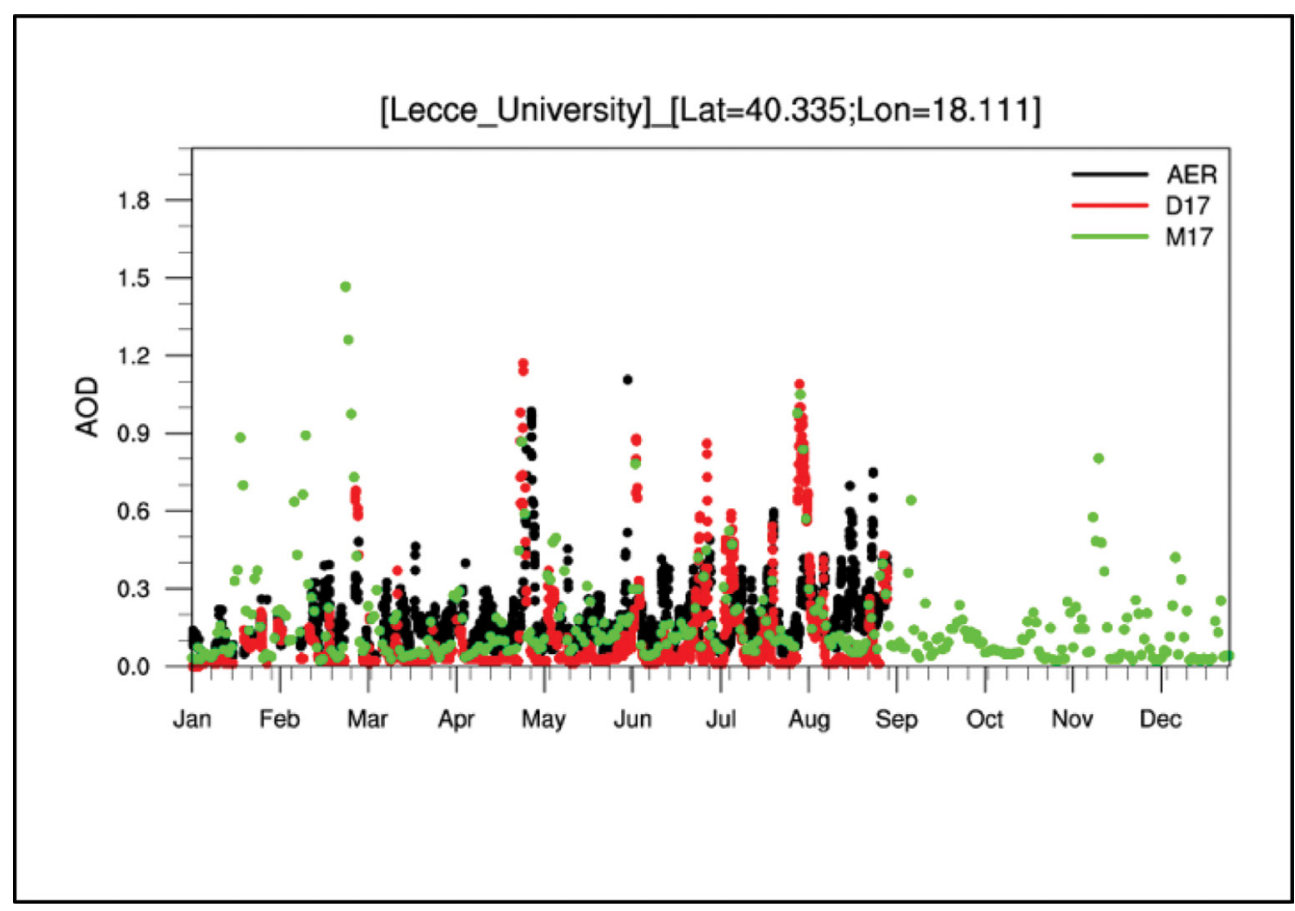

Figure 5: Comparison of the daily average of AOD at $550 \mathrm{~nm}$ : 'dust-only' (D17) simulation and 'MOZART-MOSAIC' (M17) simulation against AERONET AOD level 2 at Lecce station (AER).

simulation where anthropogenic emissions and biogenic emissions had been added to the aerosol loading ('MOZART_MOSAIC').

The evaluation of meteorological parameters has been performed against one experimental dataset: the NCEP/NCAR reanalysis product to assess the spatial distribution of simulations results (i.e. the temperature and relative humidity at $2 \mathrm{~m}$ and the winds at $10 \mathrm{~m}$ ) to validate one of the most important driving parameters for dust source, the wind speed. The monthly average of temperature, relative humidity and wind showed a noteworthy capability of the model to reproduce the experimental evidence: small deviations are present mainly due to the different resolutions of the NCAR/NCEP reanalysis and of the model. The FDDA technique, used to nudge the meteorological parameters each 6 hours, was fundamental for these simulations.

Mineral dust source assessment and transport assessment were based mainly on datasets such as MERRA-2, MODIS and ground-based sun photometer network AERONET. On the regional scale, the comparison between the modelled AOD and the dust column mass density fields with the corresponding MODIS retrievals and MERRA-2 reanalysis showed that both WRF-Chem simulations ('DUSTONLY' and 'MOZMOSAIC') reasonably resolve the spatial evolution and the Saharan dust sources but largely overestimate dust load and AOD over the North Africa regions by a factor of 10 for the column mass density and by a factor of 2 for the AOD and still slightly overestimate also over the Mediterranean countries. The modelling overestimate is also evident in the comparison of both simulations, with the daily 
averages of AERONET AOD $(550 \mathrm{~nm})$ at Rome and Naples stations. This is not so evident in the 'DUSTONLY' simulation when AERONET measurements at Lecce and Naples stations recorded higher values. This could be due to a dust intrusion that was offset by the M17 simulation. To examine this question, it will be necessary to analyse detailed AOD maps for that period.

Given the preliminary results, future developments and analyses are necessary. First, the assessment of the natural and anthropogenic aerosols is still embryonal. Then, it would be important to introduce further data not used by now (e.g. AOD from MERRA-2 and MISR, aerosol index from Ozone Monitoring Instrument (OMI)) to better understand the dust outbreaks that occurred during the period considered in this study. Furthermore, the dust emission mechanisms actually implemented in WRF-Chem (namely the GOCART/AFWA and dust University of Cologne (UoC)) should be better screened as well. Finally, another possibility would be simply utilizing more AERONET stations in order to extrapolate more robust statistical parameters (e.g. RMSE, BIAS and correlation coefficient) but also a more comprehensive experimental dataset, or field campaigns, with a aerosol speciation to discriminate the contribution of natural and anthropogenic aerosols over the Mediterranean basin.

\section{REFERENCES}

[1] Ginoux, P., Prospero, J.M., Gill, T.E., Hsu, N.C. \& Zhao, M., Global-scale attribution of anthropogenic and natural dust sources and their emission rates based on modis deep blue aerosol products, pp. 1-36, 2012.

[2] Twomey, S. \& Twomey, S., The influence of pollution on the shortwave albedo of clouds. Journal of the Atmospheric Sciences, 34(7), pp. 1149-1152, Jul. 1977.

[3] Baker, M.B., Corbin, R.G. \& Latham, J., The influence of entrainment on the evolution of cloud droplet spectra: I. A model of inhomogeneous mixing. Quarterly Journal of the Royal Meteorological Society, 106(449), pp. 581-598, Jul. 1980.

[4] Albrecht, B.A., Aerosols, cloud microphysics, and fractional cloudiness. Science, 245(4923), pp. 1227-30, Sep. 1989.

[5] Ginoux, P., Prospero, J.M., Torres, O. \& Chin, M., Long-term simulation of global dust distribution with the GOCART model: Correlation with North Atlantic Oscillation. Environmental Modelling and Software, 19(2), pp. 113-128, 2004.

[6] Engelstaedter, S., Tegen, I. \& Washington, R., North African dust emissions and transport. Earth-Science Reviews, 79(1-2), pp. 73-100, 2006.

[7] Rizza, U. et al., WRF-Chem model simulations of a dust outbreak over the central Mediterranean and comparison with multi-sensor desert dust observations. Atmospheric Chemistry and Physics, 17(1), pp. 93-115, Jan. 2017.

[8] Gobbi, G.P., Kaufman, Y.J., Koren, I. \& Eck, T.F., Classification of aerosol properties derived from AERONET direct sun data. Atmospheric Chemistry and Physics, 7(2), pp. 453-458, Jan. 2007.

[9] Deroubaix, A., Martiny, N., Chiapello, I. \& Marticorena, B., Suitability of OMI aerosol index to reflect mineral dust surface conditions: Preliminary application for studying the link with meningitis epidemics in the Sahel. Remote Sensing of Environment, 133, pp. 116-127, 2013.

[10] Dubovik, O. \& King, M.D., A flexible inversion algorithm for retrieval of aerosol optical properties from Sun and sky radiance measurements. Journal of Geophysical Research: Atmospheres, 105(D16), pp. 20673-20696, 2000. 
[11] Bey, I. et al., Global modeling of tropospheric chemistry with assimilated meteorology: Model description and evaluation. Journal of Geophysical Research: Atmospheres, 106(D19), pp. 23073-23095, Oct. 2001.

[12] Lamarque, J.F. et al., CAM-chem: Description and evaluation of interactive atmospheric chemistry in the Community Earth System Model. Geoscientific Model Development, 5(2), pp. 369-411, Mar. 2012.

[13] Gelaro, R. et al., The modern-era retrospective analysis for research and applications, version 2 (MERRA-2). Journal of Climate, 30(14), pp. 5419-5454, Jul. 2017.

[14] Grell, G.A. et al., Fully coupled 'online' chemistry within the WRF model. Atmospheric Environment, 39(37), pp. 6957-6975, 2005.

[15] Fast, J.D. et al., Evolution of ozone, particulates, and aerosol direct radiative forcing in the vicinity of Houston using a fully coupled meteorology-chemistry-aerosol model. Journal of Geophysical Research: Atmospheres, 111(21), p. D21305, Nov. 2006.

[16] Basart, S. et al., Extensive comparison between a set of European dust regional models and observations in the Western Mediterranean for the summer 2012 Pre-ChArMEx/ TRAQA campaign. in Air Pollution Modeling and its Application XXIV, Cham:Springer, pp. 79-83, 2016.

[17] Huneeus, N. et al., Global dust model intercomparison in AeroCom phase i. Atmospheric Chemistry and Physics, 11(15), pp. 7781-7816, Aug. 2011.

[18] Rizza, U. et al., Sensitivity of WRF-Chem model to land surface schemes: Assessment in a severe dust outbreak episode in the Central Mediterranean (Apulia Region). Atmospheric Research, 201(August 2017), pp. 168-180, 2017.

[19] Tanaka, T.Y. \& Chiba, M., A numerical study of the contributions of dust source regions to the global dust budget. Global and Planetary Change, 52(1-4), pp. 88-104, Jul. 2006.

[20] Ginoux, P. et al., Sources and distributions of dust aerosols simulated with the GOCART model. Journal of Geophysical Research: Atmospheres, 106(D17), pp. 20255-20273, Sep. 2001.

[21] Prospero, J.M., Ginoux, P., Torres, O., Nicholson, S.E. \& Gill, T.E., Environmental characterization of global sources of atmospheric soil dust identified with the Nimbus 7 Total Ozone Mapping Spectrometer (TOMS) absorbing aerosol product. Reviews of Geophysics, 40(1), p. 1002, Feb. 2002.

[22] Washington, R. et al., African climate change: Taking the shorter route. Bulletin of the American Meteorological Society, 87(10), pp. 1355-1366, Oct. 2006.

[23] Koren, I. et al., The Bodélé depression: A single spot in the Sahara that provides most of the mineral dust to the Amazon forest. Environmental Research Letters, 1(1), p. 014005, Oct. 2006.

[24] Kallos, G. et al., Ten-year operational dust forecasting - Recent model development and future plans. IOP Conference Series: Earth and Environmental Science, 7(1), p. 012012, Mar. 2009.

[25] Moulin, C. et al., Satellite climatology of African dust transport in the Mediterranean atmosphere. Journal of Geophysical Research: Atmospheres, 103(D11), pp. 1313713144, Jun. 1998.

[26] Dee, D.P. et al., The ERA-Interim reanalysis: Configuration and performance of the data assimilation system. Quarterly Journal of the Royal Meteorological Society, 137(656), pp. 553-597, Apr. 2011.

[27] Kumar, R., Barth, M.C., Pfister, G.G., Naja, M. \& Brasseur, G.P., WRF-Chem simulations of a typical pre-monsoon dust storm in northern India: Influences on 
aerosol optical properties and radiation budget. Atmospheric Chemistry and Physics, 14(5), pp. 2431-2446, Mar. 2014.

[28] Morrison, H., Thompson, G. \& Tatarskii, V., Impact of cloud microphysics on the development of trailing stratiform precipitation in a simulated squall line: Comparison of one- and two-moment schemes," Monthly Weather Review, 137(3), pp. 991-1007, Mar. 2009.

[29] Iacono, M.J., Delamere, J.S., Mlawer, E.J., Shephard, M.W., Clough, S.A. \& Collins, W.D., Radiative forcing by long-lived greenhouse gases: Calculations with the AER radiative transfer models. Journal of Geophysical Research: Atmospheres, 113(13), p. D13103, Jul. 2008.

[30] Nakanishi, M. \& Niino, H., An improved Mellor-Yamada Level-3 model: Its numerical stability and application to a regional prediction of advection fog. Boundary-Layer Meteorology, 119(2), pp. 397-407, May 2006.

[31] Niu, G.Y. et al., The community Noah land surface model with multiparameterization options (Noah-MP): 1. Model description and evaluation with local-scale measurements. Journal of Geophysical Research: Atmospheres, 116(12), p. D12109, Jun. 2011.

[32] Grell, G.A. \& Freitas, S.R., A scale and aerosol aware stochastic convective parameterization for weather and air quality modeling. Atmospheric Chemistry and Physics, 14(10), pp. 5233-5250, May 2014.

[33] Emmons, L.K. et al., Description and evaluation of the Model for Ozone and Related chemical Tracers, version 4 (MOZART-4). Geoscientific Model Development, 3(1), pp. 43-67, 2010.

[34] Zaveri, R.A., Easter, R.C., Fast, J.D. \& Peters, L.K., Model for Simulating Aerosol Interactions and Chemistry (MOSAIC). Journal of Geophysical Research: Atmospheres, 113(13), pp. 1-29, 2008.

[35] Wiedinmyer, C. et al., The Fire INventory from NCAR (FINN): A high resolution global model to estimate the emissions from open burning. Geoscientific Model Development, 4(3), pp. 625-641, 2011.

[36] Kalnay, E. et al., The NCEP/NCAR 40-year reanalysis project. Bulletin of the American Meteorological Society, 77(3), pp. 437-471, Mar. 1996.

[37] Fécan, F., Marticorena, B. \& Bergametti, G., Parametrization of the increase of the aeolian erosion threshold wind friction velocity due to soil moisture for arid and semiarid areas. Annales Geophysicae, 17(1), pp. 149-157, 1999.

[38] Salomonson, V.V., Barnes, W.L., Maymon, P.W., Montgomery, H.E. \& Ostrow, H., MODIS: Advanced facility instrument for studies of the Earth as a system. IEEE Transactions on Geoscience and Remote Sensing, 27(2), pp. 145-153, Mar. 1989.

[39] Holben, B.N. et al., AERONET-A federated instrument network and data archive for aerosol characterization. Remote Sensing of Environment, 66(1), pp. 1-16, Oct. 1998.

[40] Shen, S., Ostrenga, D. \& Vollmer, B., Long-term global aerosol products from NASA reanalysis MERRA-2 Available at GES DISC. American Geophysical Union Fall Meeting 2015, Abstract id. A31D-0095, 2015.

[41] Chang, J.S. et al., A three-dimensional Eulerian acid deposition model: Physical concepts and formulation. Journal of Geophysical Research, 92(12), p. 14681, Dec. 1987.

[42] Rizza, U., Anabor, V., Mangia, C., Miglietta, M.M., Degrazia, G.A. \& Passerini, G., WRF-chem simulation of a Saharan dust outbreak over the Mediterranean regions," Ciência e Nature, 38(0), p. 330, Jul. 2016. 